\title{
REFLECTION
}

\section{White Nights}

\author{
Michal Shani, $M D, M P H^{1,2}$
}

'Department of Family Medicine, Central District, Clalit Health Service, Rehovot, Israel

${ }^{2}$ Department of Family Medicine, Sackler Faculty of Medicine, Tel Aviv University, Israel

\begin{abstract}
"How can you sleep at night after you ruined my life?" Arthur, a veteran patient of mine, implored after receiving his test results. This essay recounts my experience as a physician in coping with an extremely anxious patient, its influence on me, and some of my reflections on the ensuing white nights.
\end{abstract}

Ann Fam Med 2016;14:79-80. doi: 10.1370/afm.1884.

"H Ow can you sleep at night after you ruined my life?" Arthur implored, overcome by anxiety with his recent test results. The findings seemed threatening to him. He was sure they indicated some kind of incurable disease.

Arthur was a veteran patient of mine. He had long white hair held in a ponytail with a thin rubber band, combed carefully over his expanding bald spot. He recently retired from his work as a chemist after toiling for more than 30 years in a hospital laboratory. His 3 children were in their late teens and early 20s, relatively young for someone his age. $\mathrm{He}$ met and married his much younger wife when he was nearly 50. During the decade I had known him, he was always convinced a great calamity awaited him, anxiety was his constant companion. As impatient as a child, he was also curious, questioning, and open, and he constantly sought words of solace or a soothing hand. Our sessions would often begin with him attacking me verbally, after which he would be relieved to hear that all was well. Stormy Arthur. After my calming reassurances he always thanked me for being so patient with him.

This time Arthur was overwhelmed with worry. He was waiting for the biopsy results of a nodule that was first detected on a chest radiograph. He was convinced he was going to die from cancer. He came into my office shooting in all directions. "Why didn't you send me for these tests earlier? Had we known these results sooner, I could have recovered. Where is your sense of responsibility? What kind of doctor are you? What will happen to my family? How can you sleep at night after what you have done to me?"

Arthur began coming in on an almost daily basis, waiting outside my office, brewing in his fear. He would rush into my office, repeatedly firing these questions at me. "Where were you until now? How irresponsible can you be? Why are you suddenly silent? How can you sleep at night after making such a mistake by not sending me to these tests on time?"

I was stunned into silence, something that does not happen to me often. Yet the intensity of his accusations was disturbing. I merely listened, allowing him to vent. I realized it was futile to explain the reasons behind my choices and that the medical procedures were appropriate for such results. It would sound like an attempt to defend myself against a lawsuit.

Yet Arthur's questions left me no peace. I checked and rechecked his files and my notes, as well as those of the other physicians with whom he consulted. There was no medical mistake. Even if the worst happened, I couldn't have prevented it. Even had the tests been conducted months earlier, they wouldn't have changed a thing.
Michal Shani, MD, MPH

1 Duvdevan st. Mazkeret

Batya, Israel

michal.shani@gmail.com 
Still, his image and accusing face would not leave me. I found myself unsettled every time his name appeared on my patient list, when receiving a message from him, or even when hearing his voice in the hallway. His eyes followed me everywhere. How can you sleep at night? How can you sleep at night? How can you sleep at night?

The results came back. All was in order. The frightening and horrible disease dissolved. I was forgiven. I resumed my status as the good doctor-one who can be relied upon and whose words quiet the storm.

Yet despite the positive results and that all ended well, the storm within me did not immediately calm. Arthur's questions continued to invade my thoughts, echoing in my head: How can you sleep at night?

How can you sleep at night? I couldn't tell Arthur my truthful answer: I can't sleep at night. I am still worried about what could have happened, but did not. I am still questioning whether there was something else I should have done.

I have had quite a few sleepless nights since becoming a physician. The thought that I may have forgotten something for one of my patients, the worry that I could have done something better, disturbs me at times, keeping me awake. Any mistake or near-mistake leads to endless ruminations and white nights and sudden awakenings after which I create long lists of things I need to do. Not everything stands the test of time in the morning, but I know that the day these terrified awakenings cease, I need to find a different profession.

I have come to acknowledge and accept that white nights are an expected part of being a physician. I have come to understand that my concern for a patient is not always easily quelled by good news.

I was taught that an important part of my role as physician is to listen, to be there for my patients during their difficult times. To give hope, a good word, comfort. To contain their difficulties without judgment. To simply be. I am now learning to apply some of this wisdom when listening to myself as well.

To read or post commentaries in response to this article, see it online at http://www.annfammed.org/content/14/1/79.

Key words: family physician; family practice; physician-patient relationship; anxiety

Submitted June 26, 2015; submitted, revised, September 27, 2015; accepted October 30, 2015.

Acknowledgment: I would like to thank Aya Rice for her advice and support. 